\title{
A case of myocardial bridging over the right coronary artery diagnosed by coronary angiography
}

\section{Koroner anjiyografi ile tanımlanan să̆ koroner arter üzerinde myokardiyal köprüleşme olgusu}

\author{
Hekim Karapınar*, Zekeriya Küçükdurmaz, İbrahim Gül, Hasan Ali \\ Gümrükcüoğlu, Ahmet Yılmaz
}

Department of Cardiology (Assist. Prof. H. Karapınar, MD, Assist. Prof. Z. Küçükdurmaz, MD, Assist. Prof. İ. Gül, MD, Assoc. Prof. A. Yılmaz, MD), Cumhuriyet University School of Medicine, TR-58140 Sivas, Department of Cardiology (H. A. Gümrükcüoğlu, MD), Yüzüncüyıl University School of Medicine, TR-65000 Van

\begin{abstract}
Angiographically evident myocardial bridges confined to the other arteries rather than the left anterior descending artery is very rare in the literature. Also cardiac computerized tomography studies and postmortem studies demonstrated that myocardial bridges are not as rare as the angiographic series and may be confined to the other arteries rather than the left anterior descending. We reported a very rare case with myocardial bridge on right coronary artery diagnosed by coronary angiography causing severe obstruction. We want to share this angiographically visible myocardial bridge confined to the right coronary artery and discuss the potential reasons for the frequency dilemma among different diagnostic tools.
\end{abstract}

Keywords: Myocardial bridging, coronary artery disease, coronary angiography

\section{Özet}

Sol ön inen koroner arter dışındaki arterler üzerine yerleşen anjiyografik olarak tanımlanan myokardiyal köprüleşme olguları çok nadir olarak bildirilmiştir. Ancak çokkesitli bilgisayarlı tomografi ve postmortem otopsi çalışmalarında anjiyografik olarak tanımlanandan çok daha sık olarak ve sol anterior inen arter harici diğer arterler üzerinde de myokardiyal köprüleşme olduğu bildirilmiştir. Bu yazıda koroner anjiyografide sağ koroner arterde boğulmaya yol açan çok nadir bir olguyu bildirdik. Ve bu olgu ışığında değişik görüntüleme yöntemleri ile değişik sıklıklarda myokardiyal köprüleşme izlenmesinin olası sebeplerini tartıştık.

Anahtar sözcükler: Myokardiyal köprüleşme, koroner arter hastalığı, koroner anjiyografi

Geliş tarihi/Received: October 20, 2011; Kabul tarihi/Accepted: January 10, 2012

\section{*Corresponding author:}

Dr. Hekim Karapınar, Kardiyoloji Anabilim Dalı, Cumhuriyet Üniversitesi Tıp Fakültesi TR58140 Sivas. E-mail: drhekim@yahoo.com

\section{Introduction}

Myocardial bridging (MB) is a congenital condition that a segment of a major coronary artery courses within the myocardium though the coronary artery is tunneled through a part of the myocardium. It is usually confined to a single vessel which is usually the mid segment of the left anterior descending artery (LAD). It is usually asymptomatic but may be associated with acute coronary syndromes, arrhythmias, myocardial ischemia and sudden cardiac death. It has been reported as an incidental finding in many cases. It is more commonly identified at autopsy but occasionally diagnosed by coronary 
angiography. Narrowing of the coronary lumen during systole and releasing during diastole typically shows a MB during the coronary angiography. Angiographically visible MB's are rare and usually found on the LAD. Identification of $\mathrm{MB}$ on the right coronary artery (RCA) is uncommon. We reported a case of angiographically identified MB on the RCA.

\section{Case report}

59-year-old male was presented with exertional angina pectoris. He had been a massive smoker but free of any cardiovascular or metabolic diseases. His family history was free of cardiovascular diseases but the diabetes. His treadmill exercise test was positive so we performed coronary angiography and it revealed non-significant lesions at the mid portion of LAD, non-dominant left circumflex artery with high-grade stenosis at the proximal part and the first obtuse marginal branch, and proximal totally occluded RCA. Else, distal part of the RCA was totally compressed at systole and released at diastole (Figure 1,2). Successful stent implantation was performed to the circumflex artery. We recommended medical follow-up for the RCA lesions were. The patient had described no more ischemic symptoms during the follow-up.

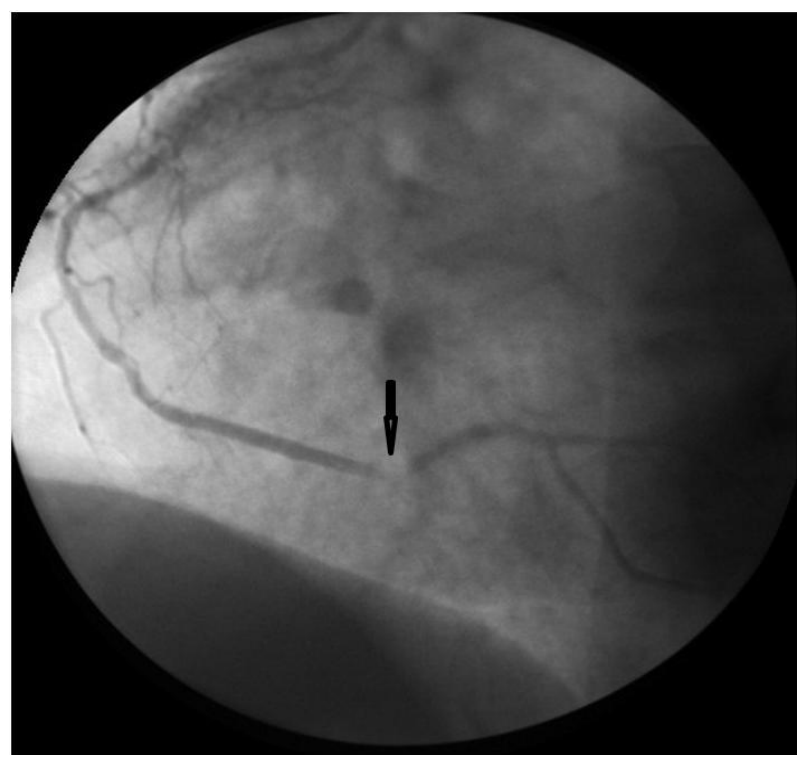

Figure 1. Systolic compression of distal part of the right coronary artery due to myocardial bridge.

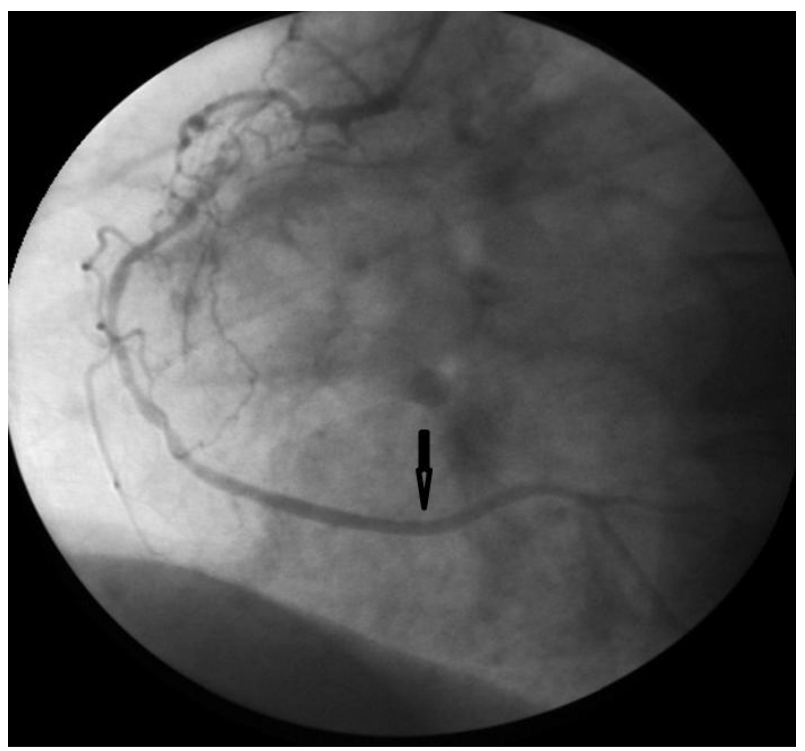

Figure 2. Diastolic decompression of distal part of the right coronary artery. 


\section{Discussion}

MB's are seen as few as $0.5 \%$ by the diagnostic coronary angiography [1]. Angiographically diagnosed MB's usually confining the LAD [1,2]. Angiographically evident MB's confine to the other arteries rather than the LAD is very rare in the literature $[1,2]$. However, cardiac computerized tomography studies and postmortem studies demonstrated that MB's are not as rare as the angiographic series and may confine to the other arteries rather than the LAD [2,3]. The differences among the angiographically evident $\mathrm{MB}$ incidence and the anatomically evident $\mathrm{MB}$ incidence depend on the unsatisfactory compress of some MB's on the coronary artery at the systole that causes insufficient loss of the wall regularity to observe during the coronary angiography. There are only few cases reported MB's confine to the right coronary artery at the angiographic studies. Increased pulmonary artery pressure was reported in some of those cases $[4,5]$. We hypothesized that the pulmonary hypertension may be a cause of the right ventricular hypertrophy so the myocardial fibers of the MB overlaying the coronary artery. So the increased strength power of the MB may beat the coronary perfusion pressure and makes the $\mathrm{MB}$ visible by the coronary angiography. In our case pulmonary artery pressure was normal but we hypothesized that the RCA perfusion may be decreased due to the chronic total occlusion of the proximal portion of the artery so the strength power of the MB may beat the decreased coronary perfusion pressure of the RCA. Our hypothesis is supported by the well known experience which describes the MB's to be more frequently and more severely appeared with the decreased blood pressure [6]. Else MB's are invisible when the myocardium of the MB is stunned or infracted [7].

We wanted to share this angiographically visible $\mathrm{MB}$ confine to the RCA and for contribution to explain its frequency dilemma among different diagnostic tools.

\section{References}

1. Irvin RG. The angiographic prevalence of myocardial bridging in man. Chest 1982; 81: 198-202.

2. Kim PJ, Hur G, Kim SY, Namgung J, Hong SW, Kim YH, Lee WR. Frequency of myocardial bridges and dynamic compression of epicardial coronary arteries: a comparison between computed tomography and invasive coronary angiography. Circulation 2009; 119: 1408-16.

3. Bezerra AJ, Prates JC, DiDio LJ. Incidence and clinical significance of bridges of myocardium over the coronary arteries and their branches. Surg Radiol Anat 1987; 9: 273-80.

4. Celik T, Iyisoy A, Kursaklioglu H. Myocardial bridging confined to the right ventricular branch of the right coronary artery in a patient with severe pulmonary hypertension. J Invasive Cardiol 2006; 18: E223-4.

5. Gurewitch J, Gotsman MS, Rozenman Y. Right ventricular myocardial bridge in a patient with pulmonary hypertension--a case report. Angiology 1999; 50: 3457.

6. Kilic H, Akdemir R, Bicer A, Dogan M. Transient myocardial bridging of the left anterior descending coronary artery in acute inferior myocardial infarction. Int $\mathrm{J}$ Cardiol 2009; 131: e112-4.

7. C. Myocardial Bridge Appearing as a Cause of Angina Pectoris after Successfully Primary Percutaneous Intervention Performed in the Setting of Anterior Myocardial Infarction. Hipokrat Kardiyoloji Dergisi 2005; 9: 330-2. 